\title{
Grassroots consortia go back to the basics
}

\section{Washington}

WITH little fanfare, a small California software company is proving that it is possible to create innovative and profitable industrial research consortia without massive government subsidies or cumbersome bureaucracies. At the same time that big industrial consortia such as Sematech and the Mi-

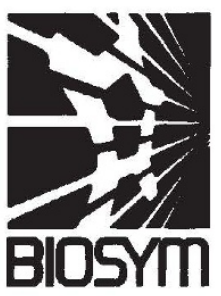
croelectronics and Computer Technology Corporation (MCC) are wracked by internal dissension and losing members, Biosym Technologies, a company based in San Diego that specializes in molecular and chemical modelling software, has started four consortia involving more than 100 industrial members and put products on the market.

Biosym has succeeded by sticking to the basics and steering clear of its members' proprietary secrets. By focusing on basic molecular modelling tools with broad application, the company has managed to find a 'generic' niche that is still state-of-the-art. Another part of the formula for success is to let its own employees - not researchers on loan from its member companies - do the work. That approach provides a buffer between the competing partners and ensures that no proprietary technology is leaked. Members meet every nine months to vote on research directions, but otherwise they simply put in their money and wait for results.

This grassroots approach to consortia has won nothing but praise. The products keep coming, and members say that they are getting what they want at a fraction of what it would have cost them to do it themselves. Last year, Biosym had total revenues of $\$ 23$ million and increased its staff by 54 per cent, becoming the 20th fastest growing US high-technology company.

Biosym's style of narrowly-focused, do-it-yourself consortia appeal to companies grown wary of costly, government-subsidized research collaborations with fuzzy research aims and power struggles between members. (Sematech, for example, operates on an annual budget of $\$ 200$ million, half from the federal government and half from its 14 industrial members.) Cray Research has started a similar consortium to develop chemical modelling software for its supercomputers, and dozens of university research groups are winning industrial funding by setting up their own small consortia to take on specific research projects.
The aim of all of these consortia is to make the best use of scarce research dollars by addressing common problems. But some do it better than others. Sematech has had a hard time finding such problems - it initially intended to research semiconductor materials, but was forced to shift to manufacturing technology when its members got nervous about jointly working in such a competitive field. In contrast, Biosym started on molecular and chemical software tools and has never looked back.

Its four consortia - polymers, catalysts, potential energy functions and a materials project that will start in July each have about 15 full-time programmers. The polymer consortium charges each of its 51 industrial members about $\$ 80,000$ a year. In exchange, it gives them new software every nine months and asks them to vote on the next project. The members get one year of exclusive access to the software, after which Biosym can sell it to anyone.

Universities may join by paying 15 per cent of the commercial rate, but they have no vote in setting the direction of research. Any company that joins late must pay all back fees.

Other consortia have similar ground rules. Cray's two-year-old UniChem project has fewer members (five) and charges more, but otherwise the meetand-steer process is the same, as is the promise of a period of exclusive use.

Industrial members say that these consortia save them from having to develop their own software but still allow them to tailor the final product to their specifications. But while basic atomic and molecular modelling tools have applications ranging from drug design to catalyst creation and materials research, not many other technologies can make the same claim.

"Anything other than software gets proprietary real quick," says George Fitzgerald, a member of the Cray Research UniChem team. When software goes beyond the basic modelling tools it enters an area where members want different features and tend to fight - or quit - if they feel that they are not getting what they need. That, of course, is something Sematech and MCC have learned only too well.

Another advantage of small consortia over in-house research teams is their ability to search the world for related technology. Biosym's academic connections have unearthed dozens of specialized algorithms and software tools, many of which were available essentially without charge. The consortia has also succeeded in finding good software that was nevertheless lying fallow because of its clumsy user interface or unusual hardware requirements.

"Biosym's been able to find bits of software from around the world that were essentially unusable," says Warren Knox, senior research manager at Dow Chemical Company, a member of the polymer consortium. "They've collected it, organized it and made sure the connections are seamless." Encouraged by Biosym's handling of 'found' software, Dow even donated an in-house molecular structure program of its own - and was delighted to see the software given a easy-to-use interface and worked into the next consortia software package.

Members of the consortia are not deterred by the thought that their competitors will have access to the same technology. "The proprietary concern is balanced with the knowledge that there are times when you just can't afford to go it alone," says Thomas Raeuchle, UniChem product manager. "And the companies only have to say what they want, not what they intend to do with it."

Rather than worrying about their competitors, members of the consortia value the collaborations as a sort of neutral zone where they can discuss shared problems without the usual trade-secrets caution. "It lets us talk to our competitors, which we wouldn't do otherwise," says Knox.

Apart from those working on software, most of the small consortia are based around university groups (such as catalysis consortia at the University of Delaware and the University of Chicago) and unique problems. For example, a number of chemical companies who are looking for alternatives to the ozone-killing chlorofluorocarbons (CFCs) have joined together to do toxicity testing on the new compounds.

But industry's romance with small consortia may not last forever. The number of problems that are generic enough to allow fierce competitors to join amiably are limited. And some industries may be at capacity.

"Companies are getting consortiumed to death," says Kenneth Peddicord, dean of engineering at Texas A\&M University. That development is not all bad, he adds: the competition for industry dollars "has sharpened the research that's going on inside" the consortia.

Industrial researchers say that such willingness to shift focus quickly to suit corporate sponsors proves that small consortia are staying flexible - a trick their big rivals have yet to learn. As long as industrial research funding remains tight, they say, small, independent consortia will continue to make sense as a way to perform high-quality research on the cheap.

Christopher Anderson 